\title{
Study of non-conventional fuels for explosives mixes
}

\section{Estudo de combustíveis não-convencionais para misturas explosivas}

\author{
Salatiel Assis Resende \\ M.Sc., PPGEM, Departamento de Mineração \\ Universidade Federal de Ouro Preto/UFOP \\ Ouro Preto, Minas Gerais, Brasil \\ salattiel@gmail.com

\section{Valdir Costa e Silva \\ PPGEM, DEMIN, \\ Universidade Federal de Ouro Preto/UFOP \\ Ouro Preto, Minas Gerais, Brasil \\ valdir@demin.ufop.br}

\section{Hernani Mota de Lima}

PPGEM, DEMIN,

Universidade Federal de Ouro Preto/UFOP

Ouro Preto, Minas Gerais, Brasil

hernani.lima@ufop.br

\begin{abstract}
The use of ammonium nitrate and fuel oil (ANFO) results in low cost blasting. Such costs may be further reduced by replacing fuel oil with alternative fuels such as biomass (biodiesel, rice straw, corn cob, sugar cane bagasse) and tires residue. This paper investigates the use of other fuels instead of fuel oil by measuring the detonation velocity (VOD) and verifying the importance of these fuels in an explosive mixture. Except for biodiesel, all the tests conducted for the mixture of ammonium nitrate and alternative fuels showed poor performance when compared with ANFO. The achieved percentage of detonation velocity (VOD) of the mixtures in relation to the ANFO were $55.4 \%$ for ammonium nitrate + rice straw, $64.9 \%$ for ammonium nitrate + corn cob, $70.1 \%$ for ammonium nitrate + sugar cane bagasse, $74.4 \%$ for ammonium nitrate + tires residue and $93.7 \%$ for ammonium nitrate + biodiesel. This study indicates that the methodology proposed can be applied as a reference for determination and preparation of explosive mixtures of fuel and oxidizing agents since in all the tests conducted the detonation of the charges occurred.
\end{abstract}

Keywords: ANFO, blasting, alternative fuels, biomass

\section{Resumo}

A utilização do ANFO (ammonium nitrate fuel oil) implica um reduzido custo de desmonte. Tais custos podem ser mais baixos ao se substituir o óleo diesel por combustiveis alternativos como biomassa (biodiesel, palha de arroz, sabugo de milho, bagaço de cana-de-açúcar) e resíduo de pneu. Esse artigo investiga o emprego de novos combustiveis, em substituição ao óleo diesel presente no ANFO via medição da velocidade de detonação e verificação do efeito desses combustiveis na mistura explosiva. Com exceção do biodiesel, todos os ensaios provenientes da mistura entre o nitrato de amônio e os combustiveis alternativos apresentaram desempenho insatisfatório comparado ao ANFO. Os percentuais obtidos de velocidade de detonação das misturas em relação à do ANFO foram de 55,4\% (NA + Casca de arroz), 64,9\% (NA + Sabugo de milho), 70,1\% (NA + bagaço de cana), 74,4\% (NA + resíduo de pneu) e 93,7\% (NA + Biodiesel). Ainda, a metodologia adotada pode ser aplicada como referência para determinação e elaboração de misturas explosivas (agentes oxidantes e combustiveis), uma vez que, nos ensaios realizados, ocorreu a detonação das cargas.

Palavras chave: ANFO, desmonte, combustiveis alternativos, biomassa.

\section{Introduction}

The importance of ANFO as an industrial explosive due to cost, safe handling and ease of use has prompted a large amount of work attempting to quantify the influence of physical properties (parameters of the explosive) to the detonation properties (parameters of the explosion). Studies of the detonation properties of ammonium nitrate and various fuels have been conducted by COOLEY (1955), DERIBAS (1999),
MIYAKI et al. (2007), ZYGMUNT (2009) and BUCZKOWSKI e ZYGMUNT (2011). Fuels used in these studies include: coal dust, confectioners sugar, aluminium powder, TNT and fuel oil. 
Clark (1987) reported a comprehensive review of ANFO detonation velocity as a function of charge diameter, charge confinement, fuel oil content, particle size, particle size distribution, loading density and moisture content. He also showed experimental curves for sensitivity to initiation (measured as the minimum detonator size required to initiate a detonation reaction) as a function of fuel oil content, charge density, particle size, particle size distribution, bulk density, number of crystalline transitions (prill density) and diatomaceous earth content. The general conclusions taken from Clark's study include:

- Detonation velocity is strongly dependent on charge diameter for charges less than $100 \mathrm{~mm}$ in diameter. Detonation velocity continues to increase in charges up to $1016 \mathrm{~mm}$ in diameter. Results are not reported for larger charge diameters.

- Increasing the stiffness of charge confinement up to a critical value will increase the VOD of a charge of given diameter and density.

- Critical diameter (the minimum diameter at which a detonation will propagate) decreases as the stiffness of the charge confinement increases.

- Maximum heat of detonation is found in an oxygen balanced ANFO mix of $94.2 \% \mathrm{AN}$ and $5.8 \%$ FO. Maximum VOD is found at a slightly lower FO content. However, VOD decreases sig-

\section{Materials And Methods}

The materials (fuels) used in this study were sugar cane bagasse, rice straw, corn cob, tires residue and biodiesel considered fuels capable of reacting with an oxidizer, generally oxygen in a combustion reaction.

The methods adopted include: choice of materials, thorough preparation,
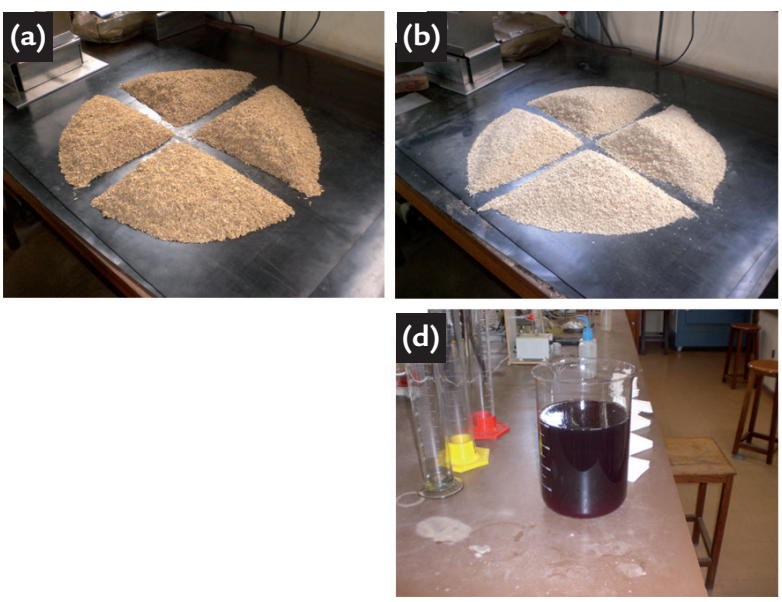
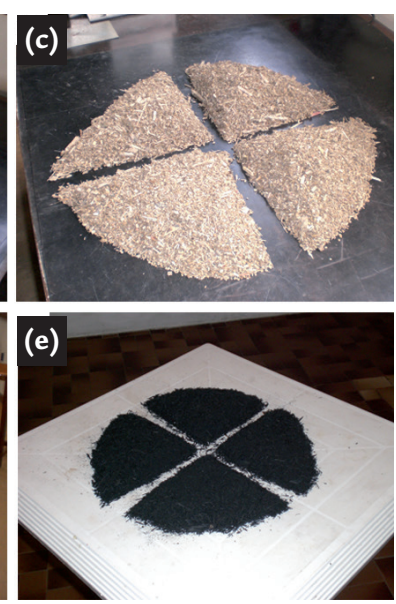

and the accessories are activating in accordance with the value provided by the manufacturer (SILVA, 2006).

In Brazil few companies share the market of explosives for mining and construction (MUNARETI et al., 2002). Allied to this reality, the lack of information on the use of ANFO for most of the mines and quarries makes the same become dependent on products and prices set by explosive manufacturing industries. The use of ANFO implies a reduced cost of blasting. However, such costs can be even lower when replacing diesel oil by alternative fuels such as biomass (biodiesel, rice straw, corn cob, sugar cane bagasse) and tires residue. According to Silva (2006), these materials combine with excess oxygen to prevent the explosive mixture formation of $\mathrm{NO}, \mathrm{NO}_{2}$, and toxic chemicals, reducing the temperature of the reaction "heat robbers".

On the other hand, the explosive mixture containing an oxidising agent (ammonium nitrate, calcium nitrate, potassium nitrate, sodium nitrate etc.) ensures the oxidation of carbon, which prevents the formation of $\mathrm{CO}$. This also makes their disassembly more environmentally satisfactory.

This paper investigates the use of new fuels to replace diesel oil in the ammonium nitrate fuel oil (ANFO) by measuring the detonation velocity and verifies the efficacy of these fuels in the explosive mix.

sampling, elementary analyses, determination of chemical balance and oxygen balance AN + fuel mix and detonation field tests to determine VOD recording.

Primary samples were randomly taken in order to guarantee that all parties have the same chance of being selected. Particle size of the samples were then

reduced in order to increase the surface area (CLARK, 1987). Residues of tires were acquired in a company dealing with retreading tires.

The increments (Figure 1) were subjected to homogenization and quartering technique in order to obtain the proper amount for elemental analysis.

Figure 1

Increments of fuel that will be used to compose sample

a) - rice straw,

b) - corn cob

c) - sugar cane bagasse,

d) - biodiesel, and

e) - tires residue. 


\section{Sample Preparation}

The basis was a sample primary mass exceeding $2 \mathrm{~kg}$ for each solid fuel made by drying in an oven in order to reduce moisture. The homogenization was performed in the same canvas,

\section{Elementary analysis}

According to Dick et al. (2005) for explosive mixtures, the energy released is optimized for oxygen balance of zero. In order to determine the detonation reaction, prior knowledge of the chemical composi- quartered with a Jones splitter, and conical piled until generating an amount of $5 \mathrm{~g}$ for each fuel. A sample of 4 litres of biodiesel composed of $96 \%$ diesel and $4 \%$ biofuel in mass was collected

tion of these fuels is recommended. The elemental analysis of fuels aims to determine the chemical composition thereof for the preparation of a formula to establish a minimum allowing reaction between the fuel and randomly at pump stations. The sample was placed in a beaker and stirred. An aliquot of $5 \mathrm{ml}$ was collected and sent for elemental analysis along with other fuels.

oxidizing agent (ammonium nitrate). The analysis was performed in a Perkin Elmer elemental analyser. Table 1 shows the results of elemental analysis with the mass percentage of each element present in each sample.
Table 1

Percentage by mass of each element present in the samples

\section{Calculation of stoichiometric formula}

The stoichiometric formula indicates the elements that form the substance as well as the proportion in number of atoms of these elements expressed in whole numbers and the smallest possible (Feltre, 1995).
Elementary chemistry analyses

\begin{tabular}{c|c|c|c|c}
\hline & $\mathrm{C}(\%)$ & $\mathrm{H}(\%)$ & $\mathrm{N}(\%)$ & $\mathrm{O}(\%)$ \\
\hline Corn cob & 42.87 & 6.20 & 0.61 & 50.32 \\
\hline Rice straw & 34.02 & 4.73 & 0.41 & 60.84 \\
\hline Sugar cane bagasse & 43.28 & 6.00 & 0.94 & 49.78 \\
\hline Tire residue & 85.60 & 6.73 & 0.45 & 7.23 \\
\hline Biodiesel & 60.86 & 9.12 & 0.15 & 29.87 \\
\hline
\end{tabular}

Table 2 shows the minimum formula of each fuel from the elementary chemical analysis.
Table 2

Minimum formula of each fuel used.

\begin{tabular}{|c|c|c|c|c|c|}
\hline \multirow{2}{*}{ Materials } & \multicolumn{4}{|c|}{ Mass Composition (\%) } & \multirow{2}{*}{ Stoichiometric formula } \\
\hline & C & $\mathrm{H}$ & $\mathrm{N}$ & $\mathrm{O}$ & \\
\hline Corn cob & 42.87 & 6.20 & 0.61 & 50.32 & $\mathrm{C}_{82} \mathrm{H}_{142} \mathrm{NO}_{72}$ \\
\hline Rice straw & 34.02 & 4.73 & 0.41 & 60.84 & $\mathrm{C}_{97} \mathrm{H}_{161} \mathrm{NO}_{130}$ \\
\hline Sugar cane bagasse & 43.28 & 6.00 & 0.94 & 49.78 & $\mathrm{C}_{54} \mathrm{H}_{89} \mathrm{NO}_{46}$ \\
\hline Tires residue & 85.60 & 6.73 & 0.45 & 7.23 & $\mathrm{C}_{222} \mathrm{H}_{209} \mathrm{NO}_{14}$ \\
\hline Biodiesel & 60.86 & 9.12 & 0.15 & 29.87 & $\mathrm{C}_{463} \mathrm{H}_{832} \mathrm{NO}_{170}$ \\
\hline
\end{tabular}

\section{Determination of the chemical reaction of oxygen and balancing}

The most explosive ingredients are composed of elements such as oxygen, nitrogen, hydrogen and carbon (DICK et al., 2005). In addition, metal elements such as aluminium may be used. For explosive mixtures, the energy released is optimized for zero balance oxygen. Zero oxygen balance is defined as the point where the mixture has sufficient oxygen to oxidize all that is combustible but that has no excess oxygen that can react with nitrogen to form nitrogen oxides, and is not deficient in oxygen, forming carbon monoxide. Thus, it becomes necessary to balance the equation. Theoretically, for an oxygen balance equal to zero, the reaction products of detonation are $\mathrm{H}_{2} \mathrm{O}, \mathrm{CO}_{2}$ and $\mathrm{N}_{2}$. However, small quantities of $\mathrm{NO}, \mathrm{CO}, \mathrm{CH}_{4}$ and $\mathrm{NH}_{2}$ can be generated. 
Ammonium nitrate + corn cob (1)

$$
326 \mathrm{~N}_{2} \mathrm{H}_{4} \mathrm{O}_{3}+2 \mathrm{C}_{54} \mathrm{H}_{89} \mathrm{NO}_{46} \rightarrow 164 \mathrm{CO}_{2}+794 \mathrm{H}_{2} \mathrm{O}+327 \mathrm{~N}_{2}
$$

Ammonium nitrate + Rice straw (2)

$$
289 \mathrm{~N}_{2} \mathrm{H}_{4} \mathrm{O}_{3}+2 \mathrm{C}_{97} \mathrm{H}_{161} \mathrm{NO}_{130} \rightarrow 194 \mathrm{CO}_{2}+739 \mathrm{H}_{2} \mathrm{O}+290 \mathrm{~N}_{2}
$$

Ammonium nitrate + Sugar cane bagasse (3)

$$
\begin{array}{r}
213 \mathrm{~N}_{2} \mathrm{H}_{4} \mathrm{O}_{3}+2 \mathrm{C}_{54} \mathrm{H}_{89} \mathrm{NO}_{46} \rightarrow 108 \mathrm{CO}_{2}+515 \mathrm{H}_{2} \mathrm{O}+214 \mathrm{~N}_{2} \\
\text { Ammonium nitrate + Tires residue }(4)) \mathrm{H}_{2} \mathrm{O}_{3}+2 \mathrm{C}_{222} \mathrm{H}_{209} \mathrm{NO}_{14} \rightarrow 444 \mathrm{CO}_{2}+2347 \mathrm{H}_{2} \mathrm{O}+1070 \mathrm{~N}_{2}
\end{array}
$$

Ammonium nitrate + biodiesel (5)

$$
2344 \mathrm{~N}_{2} \mathrm{H}_{4} \mathrm{O}_{3}+2 \mathrm{C}_{463} \mathrm{H}_{832} \mathrm{NO}_{170} \rightarrow 926 \mathrm{CO}_{2}+5520 \mathrm{H}_{2} \mathrm{O}+2345 \mathrm{~N}_{2}
$$

\begin{tabular}{|c|c|c|c|}
\hline Oxidizing agent and Fuel & Composition & Molecular Mass (g) & Mass (\%) \\
\hline Ammonium nitrate & $326 \mathrm{~N}_{2} \mathrm{H}_{4} \mathrm{O}_{3}$ & $326 \times 80=26080$ & $(26080 / 30664) \times 100=85.1$ \\
\hline \multirow[t]{2}{*}{ Corn cob } & $2 \mathrm{C}_{82} \mathrm{H}_{142} \mathrm{NO}_{72}$ & $2 \times 2292=4584$ & $(4584 / 30664) \times 100=14.9$ \\
\hline & Total & 30664 & \\
\hline Ammonium nitrate & $289 \mathrm{~N}_{2} \mathrm{H}_{4} \mathrm{O}_{3}$ & $289 \times 80=23120$ & $(23120 / 29958) \times 100=77.2$ \\
\hline \multirow[t]{2}{*}{ Rice straw } & $2 \mathrm{C}_{97} \mathrm{H}_{161} \mathrm{NO}_{130}$ & $2 \times 3419=6838$ & $(6838 / 29958)=22.8$ \\
\hline & Total & 29958 & \\
\hline Ammonium nitrate & $213 \mathrm{~N}_{2} \mathrm{H}_{4} \mathrm{O}_{3}$ & $213 \times 80=17040$ & $(17040 / 20014) \times 100=85.1$ \\
\hline \multirow[t]{2}{*}{ Sugar cane bagasse } & $2 \mathrm{C}_{54} \mathrm{H}_{89} \mathrm{NO}_{46}$ & $2 \times 1487=2974$ & $(2974 / 20014) \times 100=14.9$ \\
\hline & Total & 20014 & \\
\hline Ammonium nitrate & $1069 \mathrm{~N}_{2} \mathrm{H}_{4} \mathrm{O}_{3}$ & $1069 \times 80=85520$ & $(85520 / 91742) \times 100=\mathbf{9 3 . 2}$ \\
\hline \multirow[t]{2}{*}{ Tire residue } & $2 \mathrm{C}_{222} \mathrm{H}_{209} \mathrm{NO}_{14}$ & $2 \times 3111=6222$ & $(6222 / 91742) \times 100=6.8$ \\
\hline & Total & 91742 & \\
\hline Ammonium nitrate & $2344 \mathrm{~N}_{2} \mathrm{H}_{4} \mathrm{O}_{3}$ & $2344 \times 80=187520$ & $(187520 / 205764) \times 100=\mathbf{9 1 . 1}$ \\
\hline \multirow[t]{2}{*}{ Biodiesel } & $2 \mathrm{C}_{463} \mathrm{H}_{832} \mathrm{NO}_{170}$ & $2 \times 9122=18244$ & $(18244 / 205764) \times 100=8.9$ \\
\hline & Total & 205764 & \\
\hline
\end{tabular}

\section{Calculation of explosive mix-mass percentage}

The percentage by mass of taking into account the molecular explosive mixtures was determined weight of ammonium nitrate and

\section{Detonation tests}

To conduct the detonation tests we used schedule 80 steel pipe, cylindrical $50.8 \mathrm{~mm}$ in diameter and $1.000 \mathrm{~mm}$ long. Mixtures of fuel and dense ammonium nitrate were previously mixed and poured into the tube and kept contained (Figure 2). A silent line was first introduced and later replaced by a detonating cord connected to a booster introduced into the pipe end to ensure the initiation of the explosive column without deflagration of the same. In addition, a coaxial cable of known resistance with one end in contact with the explosive mixture, and the other connected to VOD measuring equipment was used. Upon detonation of the explosive charge, the wave travelling through the explosive column is recorded on the equipment for measuring VOD (Microtrap). Data from each test, contained in the Microtrap were unloaded and stored in a computer before initiating the next fuel present in item 2.5 of balanced reactions (Table 3 ).

Table 3

Calculation of the mass ratio between the oxidizing agent and fuel

trial. Performance evaluation of new compounds was conducted by comparing the results, taking as standard ANFO. The tests were conducted at the premises of the Capitão do Mato Mine owned by Vale and located in the municipality of Nova Lima/Minas Gerais. In order to ensure representativeness, for each mix five tests were conducted totalling thirty detonation tests, among which twenty were recorded by measuring VOD equipment. 
Figure 2

Loading the mix in the steel pipe Schedule 80.

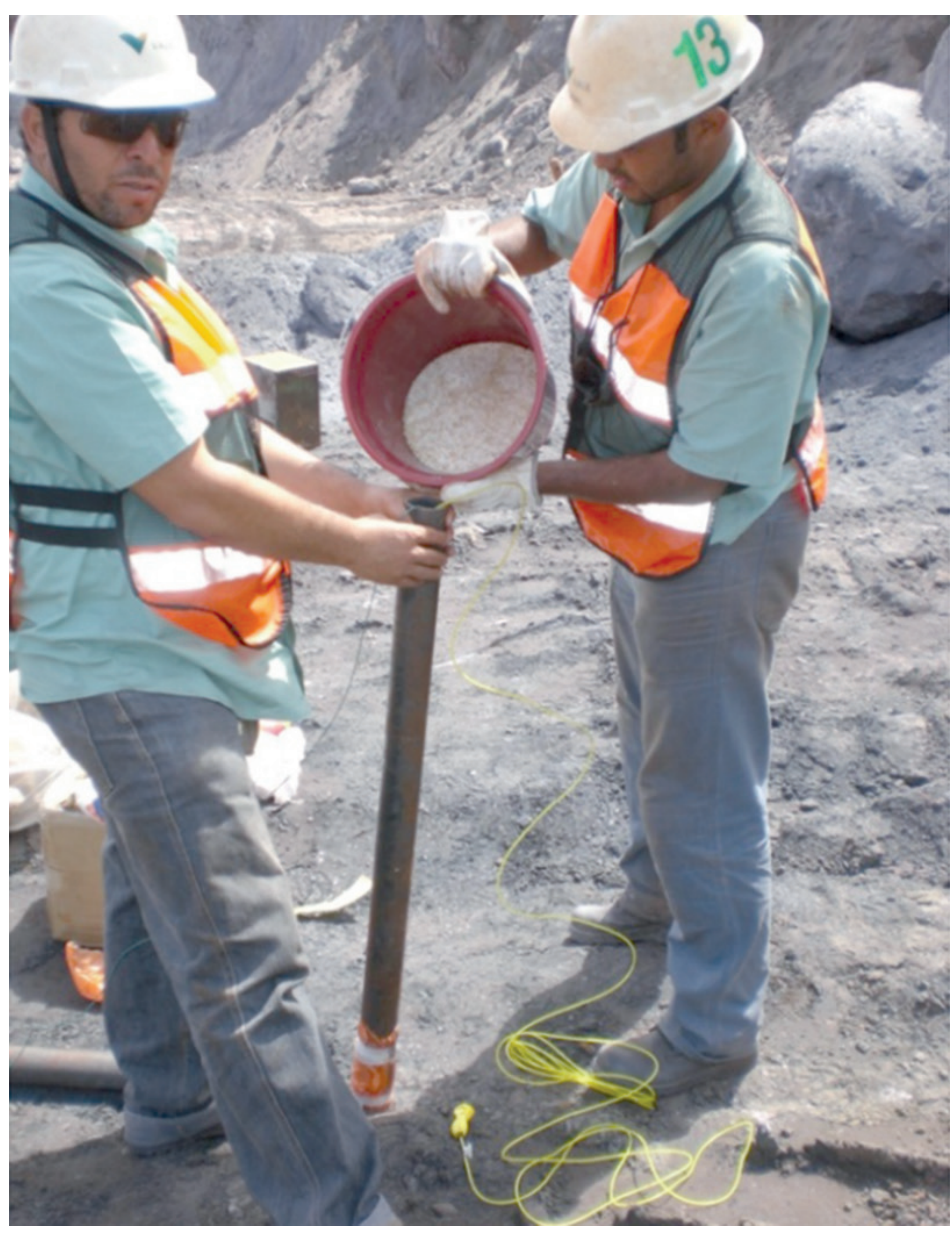

\section{Results}

Figure 3 shows the velocities of detonation for each explosive mixture of the detonation tests conducted.

Figure 3

Detonation velocity of the explosive mixes.

Figure 4 shows the variation of the average of the detonation velocity for different mixes used in the tests. It can be observed that the mixing of ammonium nitrate and biodiesel presents a satisfactory outcome in relation to other fuels, but unsatisfactory when compared with
It can be observed that except for biodiesel, all tests from the mixture of ammonium nitrate and alternative fuels

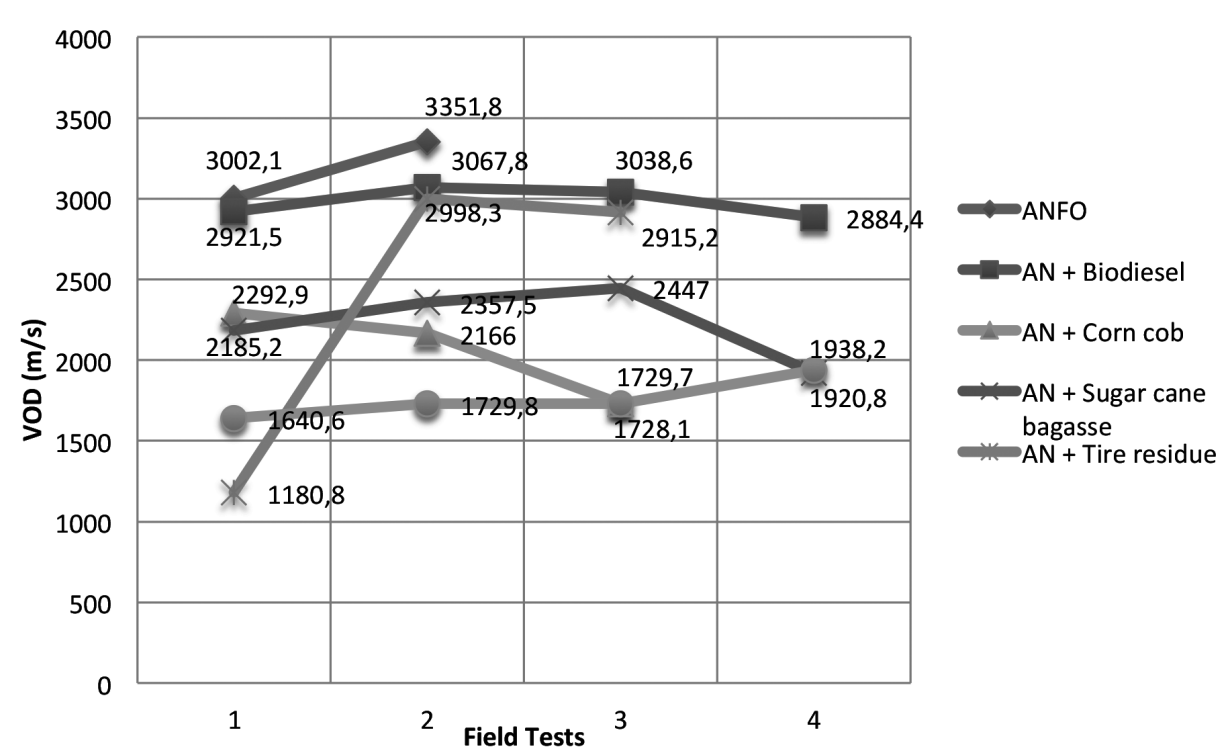

ANFO. A mixture of ammonium nitrate of the mixtures in relation to the ANFO and rice straw has the worst result with a detonation velocity averaging around $1759.2 \mathrm{~m} / \mathrm{s}$. For other fuels, the average detonation velocity varied between $1759.2 \mathrm{~m} / \mathrm{s}$ and $3.177 \mathrm{~m} / \mathrm{s}$. The achieved percentage of detonation velocity (VOD) showed poor performance compared with the result of ANFO. 


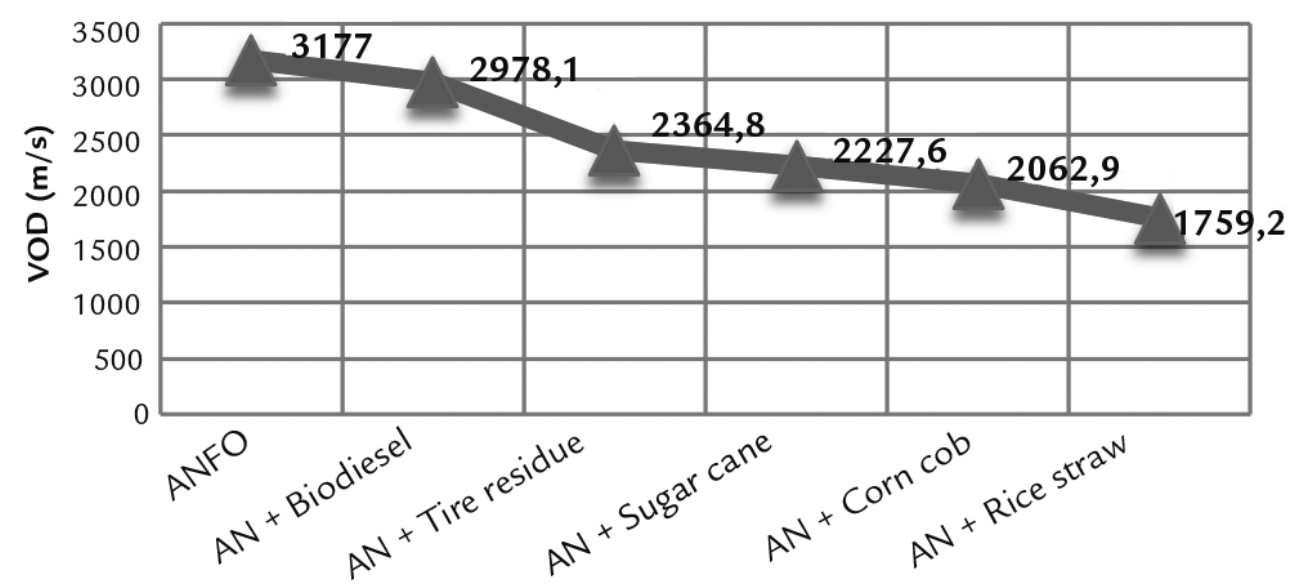

Figure 4

Variation of the VOD for the different mixes

\section{Final Comments And Recommendations}

Regarding the results presented, biodiesel showed satisfactory performance in relation to other fuels. In the field, during the preparation of the mixtures, better interaction was observed between the liquid fuel (biodiesel) with ammonium nitrate when compared to other solid fuels (corn cob, rice straw, sugar cane bagasse, tire residue).

It is also believed that the results may have been affected by the segregation of solids at the time the tubes were loaded, which likely caused a change in the proportions between the oxidizing agent and the fuels, influencing directly the detonation velocity. This study does not assess the effect of particle size on the VOD. According to Clark (1987), detonation velocity increases with decreasing particle size, certainly by reducing the segregation.
Assessing the influence of particle size on VOD for solid fuels is recommended for further studies.

This study, however, indicates that the methodology proposed can be applied as a reference for the determination and preparation of explosive mixes of fuel and oxidizing agents, since in all of the tests conducted, detonation of the charges occurred.

\section{References}

BUCZKOWSKI, D., ZYGMUNT, B. Detonation properties of mixtures of ammonium nitrate based fertilizers and fuels. Central European Journal of Energetic Materials, vol. 8, n. 2, p. 99-106, 2011.

CLARK, G.B., Principles of rock fragmentation. New York: John Wiley \& Sons, Inc, (1987.), pp. 385-430, 1987.

COOLEY, C. Report on Akremite, Mining Engineering. p. 452- 455, May 1955.

DICK, R. A.; FLETCHER, L. R. D’ANDREA, D. V. Explosives and blasting procedures manual, information circular 8925. U.S. Bureau of Mines. 2005. p.105.

FELTRE, RICARDO. Química Geral. 4.ed. São Paulo: Moderna, 1995. p.371-372.

JIMENO, C. L., JIMENO. E. L., BERMÚDEZ, P. G. Manual de Perfuracion y Voladura de Rocas. Madri: Instituto Tecnológico Geominero de Espanã, 2003. 778p.

MIYAKE, A., KOBAYASHI, H., ECHIGOYA, H., KUBOTA, S., WADA, Y., OGATA, Y., ARAI, H., OGAWA, T. Detonation characteristics of ammonium nitrate and activated carbon mixtures. Journal of Loss Prevention in the Process Industries, v.20, p. 584-588, 2007.

MUNARETI, E., KOPPE, J. C., WORSEY, P. N. Desenvolvimento e avaliação de desempenho de misturas explosivas à base de nitrato de amônio e óleo combustível, Porto Alegre. 2002. 2p.

SANCHIDRIAN, J. A. Rock fragmentation by blasting. In: Proceedings of the 9th International. Symposium on Rock Fragmentation by Blasting - Fragblast 9. Granada Spain. Sept. 2009. 872p.,

SILVA, V. C. Desmonte e transporte de rocha: Apostila de curso MIN703. Ouro Preto, 2010. p 35-36.

ZYGMUNT, B. Detonation parameters of mixtures containing ammonium nitrate and Aluminum, Central European Journal of Energetic Materials, v. 6, n.1, p. 57-66, 2009.

Received: 23 november 2011 - Accepted: 17 july 2014. 